\title{
Determination of Total Xanthone Content in the Preparation of Mangosteen Pericarp Capsules (garcinia mangostana l.) Available on the Market using UV-Visible Spectrophotometry Method
}

\author{
Delladari Mayefis ${ }^{1^{*}}$,Yandri Anugerah ${ }^{1}$, and Roslinda Rasyid ${ }^{2}$ \\ ${ }^{1}$ Bachelor of Pharmacy, Mitra Bunda Persada College of Health Sciences, Batam, Indonesia \\ ${ }^{2}$ Faculty of Pharmacy Andalas University, Padang, Indonesia
}

\begin{abstract}
The skin of Mangosteen fruit (Garcinia mangostana L.) is widely used as traditional medicine, for it contains a lot of xanthone compounds. Today, there are many products from mangosteen pericarp extract being sold on the market, one of which is the preparation of mangosteen pericarp capsules. Determining the total xanthone content in the preparation of mangosteen pericarp capsules (Garcinia mangostana L.) circulating on the market needs to be done to calculate the levels of xanthone that are not included in the preparation label. The results of the analysis with UV-Visible Spectrophotometry obtains the maximum absorption wavelength at $243 \mathrm{~nm}$ and the linear regression equation of the calibration curve that is $y=0,0568+0,0727 x$ with a value of $r=0,9999$. Validation of the analysis method showed the results of intraday precision obtained $\%$ RSD $0,34 \%, 0,17 \%$, and $0,16 \%$, interday precision of $0,23 \%, 0,35 \%$, and $0,16 \%$. The accuracy obtained was mean $\%$ recovery $95,55 \%$, limit of detection $0,35 \mu \mathrm{g} / \mathrm{ml}$ and limit of quantitation $1,15 \mu \mathrm{g} / \mathrm{ml}$. The results of the determination of the total xanthone content in the mangosteen pericarp capsules were 100,8 $\mu \mathrm{g} / \mathrm{mg}$ in sample A; $197 \mu \mathrm{g} / \mathrm{mg}$ in sample B; and 50,2 $\mu \mathrm{g} / \mathrm{mg}$ in sample C.
\end{abstract}

Keywords: Mangosteen pericarp capsule, Determination, UV-Visible Spectrophotometry, Total Xanthone.

\section{INTRODUCTION}

Health is one of the things that are valuable to everyone's life. Various ways will be done by people to be healthy ranging from prevention, health care to treatment of a disease. When the assumption of medical treatment is expensive, the use of traditional medicine becomes an alternative treatment in addition to modern medicine (Ahmad, N.R., 2012).

Indonesian people have long-time experience of using traditional plants medicine in various types of herbal preparations. Mangosteen (Garcinia mangostana L.) is one of traditional medicine which contains vitamin B1, vitamin B2, vitamin $\mathrm{C}$, iron, niacin, protein, fiber, calcium, polysaccharides, catechin, and polyphenols (Suparni et al., 2017).

The part of the mangosteen plant that is often used as medicine is the skin of the mangosteen fruit. One of the compounds contained in the skin of the mangosteen fruit is xanthone. There are 50 xanthone compounds on mangosteen rind. The most dominant derivatives of xanthone include $\alpha$-mangostin, $\beta$-mangosin, $\gamma$-mangostin, Garcinone, Gartanin, and 8-deoxygartanine (Chaverri et al., 2008).

The most common xanthone compound in the mangosteen fruit peel is $\alpha$-mangostin. The levels of $\alpha$-mangostin in young fruit peel extract,

\footnotetext{
*Corresponding author : Delladari Mayefis
}

Email : dellamayefis@gmail.com ripe rind and the bark of Garcinia mangostana by TLC-Densitometry method were 4.19\%, 15.85\% and $3.88 \%$ respectively (Agustina et al., 2014). The average total content of mangostin in mangosteen pericarp powder and ethanol extract were $9.94 \pm$ 0.88 and $36.25 \pm 4.66 \%$ b / b (Pothitirat et al., 2008).

In recent years, there have been many studies related to the efficacy of mangosteen rind, such as anti-malaria, anti-bacterial, antioxidant, anti-allergy, anti-inflammatory, anti-cancer, antiviral, anti-diabetic and anti-tuberculosis (Chaverri et al., 2008; Mahabusarakam et al., 2006; Pasaribu et al., 2012; Pradeep kumar et al., 2017; Priya et al., 2010; Putri et al., 2016; Setiawati et al., 2014).

The number of scientific evidence related to the efficacy of mangosteen fruit peel and current technological advances, making the industries both domestic and overseas bring up some preparations from the skin of mangosteen fruit such as a mangosteen fruit tea, leather capsules Mangosteen fruit, mangosteen bark, mangosteen fruit and many more. This circulating Mangosteen skin is claimed to contain efficacious xanthone but the tag does not list the xanthone levels contained in the dosage.

Based on the above, it is necessary to know the levels of the preparation of mangosteen pericarp extract on the market so that the quality of the preparation can be ascertained. One way is 
to determine the total xanthone content in the mangosteen pericarp capsule (Garcinia mangostana L.) by the UV-Visible Spectrophotometry method.

\section{METHODOLOGY \\ Materials}

Materials used include: Preparations of mangosteen pericarp capsules branded A, B, and C, mangostin standard (PT. Andalas Sitawa Fitolab; purity $\geq 98 \%$ ), Methanol (PT. Brataco), $\mathrm{FeCl}_{3} 10 \%$ solution, Aquadest.

\section{Methods}

Preparation of Sample Solutions

Each of samples was weighed $50 \mathrm{mg}$, put into a $50 \mathrm{ml}$ volumetric flask, dissolved with methanol, then the volume was filled until a solution concentration of $1000 \mu \mathrm{g} / \mathrm{ml}$ was obtained.

\section{Polyphenols Testing}

As many as $1 \mathrm{ml}$ sample solution put into a test tube then add 1-2 drops of $\mathrm{FeCl}_{3} 10 \%$ solution if it occurs dark blue or greenish-black indicates the presence of polyphenols.

\section{Preparation of Standard Solutions}

Pure substance $\alpha$-mangostin is weighed as much as $10 \mathrm{mg}$, put in a $100 \mathrm{ml}$ measuring flask. Then added by methanol, shook until dissolved, then the volume is filled to the limit mark so that a solution of $\alpha$-mangostin with a concentration of $100 \mu \mathrm{g} / \mathrm{ml}$ is obtained.

\section{Determination of Maximum Absorption Wavelength $\alpha$-mangostin}

The standard solution of $\alpha$-mangostin $10 \mu \mathrm{g}$ / ml was measured its maximum wavelength by UV-Visible spectrophotometer in the wavelength range $200-400 \mathrm{~nm}$.

\section{Making Calibration Curves of $\alpha$-mangostin \\ From the standard solution of $\alpha$-mangostin} $100 \mu \mathrm{g} / \mathrm{ml}$, a standard series solution was made with a concentration of $2,4,6,8$, and $10 \mu \mathrm{g} / \mathrm{ml}$. Then the absorbance was measured by UV-Visible spectrophotometry at a maximum wavelength of $243 \mathrm{~nm}$. Create a calibration curve between the concentration of $\alpha$-mangostin ( $\mu \mathrm{g} / \mathrm{ml}$ ) and absorbance.

\section{Determination of Total Xanthone Levels in Samples}

Sample solution $1000 \mu \mathrm{g} / \mathrm{ml}$ filtered with filter paper, then the pipette as much as $0.5 \mathrm{ml}$, put it into a $10 \mathrm{~mL}$ volumetric flask, fill it with methanol to the boundary markers, and shake it homogeneously to obtain a concentration of $50 \mu \mathrm{g}$ / ml. Determine the total xanthone level with three repetitions. Each absorbance was measured by UVVisible spectrophotometry at a maximum wavelength of $243 \mathrm{~nm}$.

\section{Validation of the Analysis Method Linearity}

Linearity was performed using five concentrations of standard solutions (2-10 $\mu \mathrm{g} /$ $\mathrm{ml})$. The calibration curve of $\alpha$-mangostin was obtained from the relationship between the concentration of $\alpha$-mangostin ( $\mu \mathrm{g} / \mathrm{ml}$ ) and absorbance. Linearity is determined based on the correlation coefficient $(r)$ of the calibration curve $\alpha$-mangostin.

\section{Precision}

Standard solutions of $\alpha$-mangostin with various levels of 6,8 and $10 \mu \mathrm{g} / \mathrm{ml}$ for three repetitions were measured on the same day for intraday precision and three consecutive days for interday precision. Precision is expressed as a Relative Standard Deviation (RSD) percent.

\section{Accuracy}

Add $5 \mathrm{ml}$ each sample solutions $10 \mu \mathrm{g} / \mathrm{ml}$ into $25 \mathrm{ml}$ volumetric flasks obtained a concentration of $2 \mu \mathrm{g} / \mathrm{ml}$ then added by to each measuring flask $\alpha$-mangostin standard solution $100 \mu \mathrm{g} / \mathrm{ml}$ as much as $1 \mathrm{ml}, 1,5 \mathrm{ml}$ and $2.5 \mathrm{ml}$ then added methanol to the boundary sign so that obtained the concentration of $\alpha$-mangostin 4,6 , and $10 \mu \mathrm{g} / \mathrm{ml}$. The absorbance solution was measured with three repetitions by UV-Visible spectrophotometer for each level.

\section{Limit of Detection and Limit of Quantitation}

Detection limits and quantitation limits are determined based on the standard deviation and slope of the $\alpha$-mangostin calibration curve.

$$
\begin{gathered}
\mathrm{LOQ}=10 \mathrm{SD} / \mathrm{S} \\
\mathrm{LOD}=3 \mathrm{SD} / \mathrm{S}
\end{gathered}
$$

$\mathrm{SD}=$ Standard deviation of the response based on either the standard deviation of the blank, the residual standard deviation of the regression line or the standard deviation of $y=$ Intercepts of regression lines and $S=$ Slope of the calibration curve.

\section{Analysis Data}

The total xanthone content in the sample solution was determined by the linear regression equation, $y=a+b x$ from the calibration curve $\alpha$ mangostin. Data analysis was carried out 
descriptively, namely the total xanthone content obtained was made in table form and narrated on the results and discussion and concluded.

\section{RESULT AND DISCUSSION}

From the research conducted, the following results were obtained.

Polyphenol testing results on samples A, B and $\mathrm{C}$ positively contain polyphenols which are indicated by changes in color to blackish green.

The obtained results of determining the maximum wavelength of the standard solution of $\alpha$-mangostin as measured by UV-Visible spectrophotometry was $243 \mathrm{~nm}$ absorption.

The results of the determination of the calibration curve of the standard $\alpha$-mangostin were obtained by the linear regression equation $y$ $=0.0568+0.0727 \mathrm{x}$.

Linearity test results obtained correlation coefficient value $(r)=0.9999$.

The results of precision determination of intraday $\alpha$-mangostin at concentrations of 6,8 , and $10 \mu \mathrm{g} / \mathrm{ml}$ obtained \% RSD respectively $0.34 \%$, $0.17 \%$ and $0.16 \%$. Determination of interday precision $\alpha$-mangostin at concentrations of 6,8 , and $10 \mu \mathrm{g} / \mathrm{ml}$ obtained \% RSD respectively $0.23 \%$, $0.35 \%$ and $0.16 \%$.

The results of the determination of the accuracy of the standard solutions of $\alpha$-mangostin 4, 6 and $10 \mu \mathrm{g} / \mathrm{ml}$ added to the $2 \mu \mathrm{g} / \mathrm{ml}$ sample solution obtained $\%$ recovery $89.34 \%, 89.97 \%$, and $92.32 \%$, respectively with an average recovery of $90.54 \%$.

The results of the determination of the detection limit and the quantitation limit were 0.35 $\mu \mathrm{g} / \mathrm{ml}$ and $1.15 \mu \mathrm{g} / \mathrm{ml}$.

The results of the determination of the total xanthone content in the mangosteen pericarp capsule preparation obtained levels of xanthone total sample A $100.8 \mu \mathrm{g} / \mathrm{mg}$, sample B $197 \mu \mathrm{g} / \mathrm{mg}$ and sample C $50.2 \mu \mathrm{g} / \mathrm{mg}$.

This study aims to determine the level of total xanthone contained in the mangosteen pericarp capsule (Garcinia mangostana L.) available on the market. Based on the literature, mangosteen peel contains a lot of xanthone compounds. Derivatives from xanthone compounds that function as a marker compound in mangosteen fruit peel are $\alpha$-mangostin so that it can be used as a reference in determining the quality of the mangosteen rind extract.

The samples used in this study were preparations of mangosteen pericarp capsules branded A, B, and C which were purchased at the Batam pharmacy. The selection of samples taken is based on several brands circulating on the market and most consumed by the public. This outstanding

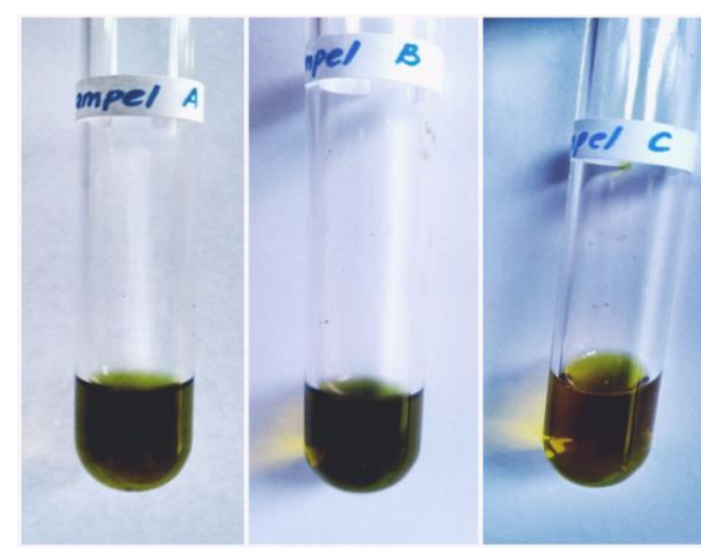

Figure 1. Polyphenols Testing

mangosteen rind capsule preparation contains mangosteen rind extract to be analyzed.

The selection of UV-Visible spectrophotometry methods on this research because it is often used for quantitative analysis of primary and secondary metabolites in herbal preparations such as total xanthone, total phenol, flavonoids, etc. In addition, this method has a fast, inexpensive, easy to use performance and has a fairly high accuracy (Pothitirat et al., 2008; Aisha et al., 2013).

Before determining the total xanthone content in the sample using UV-Visible Spectrophotometry, a polyphenol preliminary test using $\mathrm{FeCl}_{3}$ reagent is necessary. Based on the literature, compounds containing polyphenols when dripped with $\mathrm{FeCl}_{3}$ reagent will change color to dark blue or greenish-black (Harborne, 2006). From the results of the study it was found that samples $A, B$, and C positively contain polyphenols which were marked by changes in color to blackish green.

Determination of the total xanthone content in the sample using UV-Visible Spectrophotometry by determining the maximum wavelength of $\alpha$ mangostin. Before determining the wavelength, it is necessary to prepare a standard solution of $\alpha$ mangostin in methanol $100 \mu \mathrm{g} / \mathrm{ml}$. Then conducted a maximum wavelength determination of $\alpha$-mangostin using a standard solution of 10 $\mu \mathrm{g} / \mathrm{ml}$ made from the mains solution, measured its absorption at a wavelength of $200-400 \mathrm{~nm}$ so that the maximum wavelength obtained $\alpha$-mangostin $243 \mathrm{~nm}$.

The maximum wavelength obtained is in accordance with the literature which is $243 \mathrm{~nm}$. Determination of the maximum wavelength at grade determination is used to construct calibration curves, resulting in higher sensitivity 


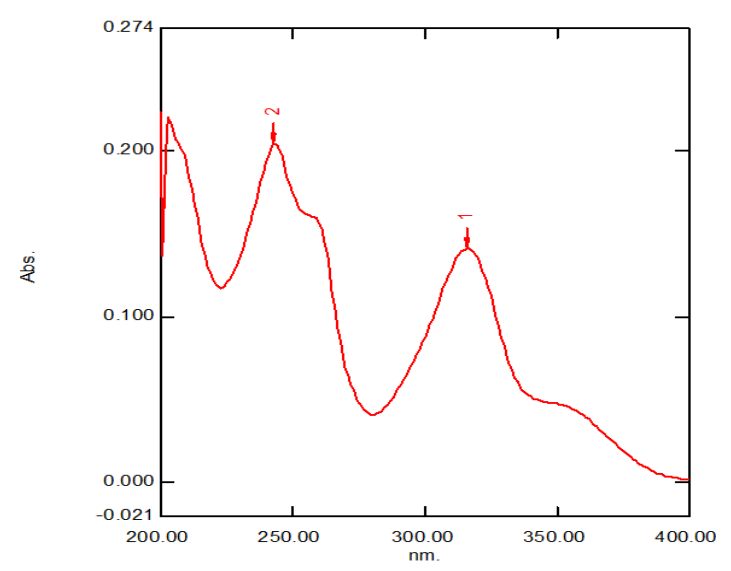

Figure 2. Spectrum of $\alpha$-mangostin in methanol solvent at $\lambda$ Maximum $243 \mathrm{~nm}$

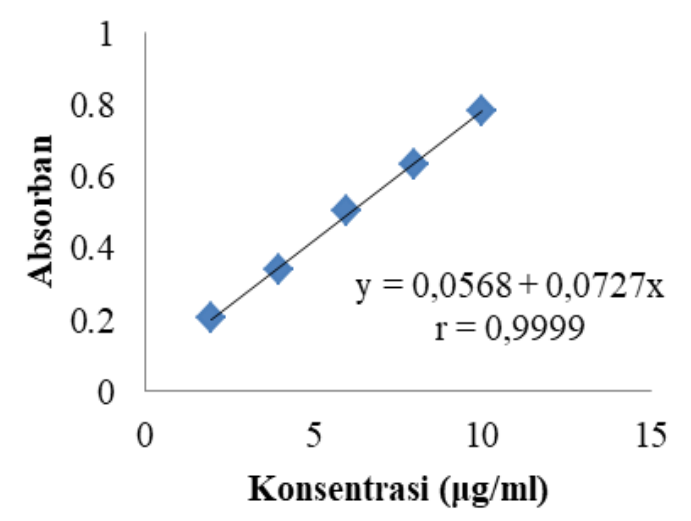

Figure 3. Calibration curve of $\alpha$-mangostin at a maximum of $243 \mathrm{~nm}$

and accuracy, obtaining maximum absorption, reducing placement errors or wavelength readings (Harmita, 2014)

The making of the calibration curve is done by making a standard series of $\alpha$-mangostin solvents in methanol solvent with concentrations of $2,4,6,8$ and $10 \mu \mathrm{g} / \mathrm{ml}$ of measured absorbaning respectively with UV-Visibel spectrophotometry at $243 \mathrm{~nm}$ wavelength. From this calibration curve, the linear regression equation $\mathrm{y}=0.0568+$ $0.0727 \mathrm{x}$. This regression equation is used to measure the total xanthone content in the sample by measuring absorbance in the sample and then put it in the regression equation.

The validation of the analysis method is carried out. Validation of the analysis method needs to be done to prove that the method used is valid and the error that occurs is still within the permissible limits. According to ICH (1996), there are several method validation parameters such as linearity, precision, accuracy, detection limits, and quantification limits (Gandjar et al., 2012).
Linearity test is determined based on the correlation coefficient (r) of the $\alpha$-mangostin calibration curve which is 0.9999 . Based on the $r-$ value obtained, it can be seen that the analysis method used meets the acceptance criteria of $0.990 \leq \mathrm{r} \leq 1$. This means that there is a correlation between the absorptions and concentration so that the use of these methods can be used to analyze the total xanthone content in the mangosteen pericarp capsule preparation (Harmita, 2004).

Precision testing is a measure that shows the degree of compatibility between individual test results measured through the spread of average individual results. The results of precision determination of intraday $\alpha$-mangostin at concentrations of 6,8 , and $10 \mu \mathrm{g} / \mathrm{ml}$ obtained RSD respectively $0.34 \%, \quad 0.17 \%$ and $0.16 \%$ while interday precision $\alpha$-mangostin at concentrations of 6,8 , and $10 \mu \mathrm{g} / \mathrm{ml}$ obtained by RSD respectively $0.23 \%, 0.35 \%$ and $0.16 \%$. Based on the RSD values obtained it can be seen that the method used has a good level of accuracy where the RSD value is $\leq 2 \%$ (Harmita, 2004).

Accuracy test was done by combining the sample and the standard $\alpha$-mangostin. Accuracy is a measure that shows the degree of closeness of the results of the analysis with the actual level of the analyte. The results of the determination of the accuracy of the standard solutions of $\alpha$-mangostin 4, 6 and $10 \mu \mathrm{g} / \mathrm{ml}$ which were added to the $2 \mu \mathrm{g} / \mathrm{ml}$ sample solution obtained\% recovery which was $89.34 \%, 89.97 \%$, and $92.32 \%$, respectively. \% recovery of $90.54 \%$. Based on these results it can be seen that $\%$ recovery has met the requirements of $80-110 \%$ (Harmita, 2004).

In this study, the limit of detection value was $0.35 \mu \mathrm{g} / \mathrm{ml}$ and the limit of quantitation value was $1.15 \mu \mathrm{g} / \mathrm{ml}$. The detection limit is the smallest number of analytes in detectable samples which still provide a significant response compared to blanks. While the limit of quantitation is a parameter in the microscopic analysis and interpreted as the smallest quantity of analyte in a sample that can still meet the criteria carefully and thoroughly (Harmita, 2004).

The results of the determination of the total xanthone content in the mangosteen pericarp capsule were obtained the total xanthone content in sample A $100.8 \mu \mathrm{g} / \mathrm{mg}$, sample B $197 \mu \mathrm{g} / \mathrm{mg}$, and sample C $50.2 \mu \mathrm{g} / \mathrm{mg}$. The difference in the total xanthone content in the preparation can be caused by differences in extraction methods used in making mangosteen rind extract so that it has a significant effect on the total xanthone content in mangosteen rind extract (Andayani et al., 2015). Total xanthone levels are also influenced by the mangosteen rind used, temperature, humidity, soil 
conditions, rainfall, and geographical location (Agustina et al., 2014; Muchtaridi et al., 2016).

\section{CONCLUSION}

Based on the results of the research that has been done can be concluded that the levels of total xanthone contained in mangosteen pericarp capsules in sample A $100.8 \mu \mathrm{g} / \mathrm{mg}$, sample B 197 $\mu \mathrm{g} / \mathrm{mg}$ and sample C $50.2 \mu \mathrm{g} / \mathrm{mg}$.

\section{REFERENCES}

Ahmad, N.R. (2012). Cara mudah mencegah dan mengobati kanker dengan ramuan tradisional dan alami. Yogyakarta: Aulya Publishing.

Suparni, I. and Wulandari, A. (2017). Sehat tanpa obat dengan manggis. Yogyakarta: Rapha Publishing.

Chaverri, J.P., Rodriguez, N.C., Ibarra, M.O., and Rojas, J.M.P. (2008). Medicinal Properties of Mangosteen (Garcinia mangostana). Food and Chem. Tox, 46, 3227-3239.

Agustina, R., Andayani, R.,and Dachriyanus. (2014). Development and validation of Thin-Layer Chromatographic method for determination of $\alpha$-mangostin in young pericarp, ripe pericarp and bark extract of Garcinia mangostana L. using TLC-Densitometry. Int. J. Res. Pharm. Sci, 5(4), 294-298.

Pothitirat, W. and Gritsanapan, W. (2008). Quantitative analysis of total mangostins in Garcinia mangostana fruit rind.J Health Res, 22(4), 161-166.

Mahabusarakam, W., Kuaha, K., Wilairat, P., and Taylor, W.C. (2006). Prenylated xanthones as potential antiplasmodial substances, Planta Med., 72(10), 912-916.

Pasaribu, F., Sitorus, P.,and Bahri, S. (2012). Uji Ekstrak Etanol Kulit Buah Manggis (Garcinia mangostana L.) Terhadap Penurunan Kadar Glukosa Darah. Journal of Pharmaceutics and Pharmacolog, 1(1), 1-8.

Pradeep kumar, S.V., S. B. Puranik., and Nandini, B. N. (2017). Evaluation of Alpha-Mangostin, Isolated and Purified from the Crude Extract of Garcinia mangostana for the AntiDiabetic, Anti-Inflammatory and Antioxidant Activity. Ijppr.Human, 8(2), 75-95.

Priya, V., Jainu, M., Mohan, S.K., Saraswathi, P., and Gopan, C.S. (2010). Antimicrobial Activity of Pericarp Extract of Garcinia Mangostana Linn. International Journal of Pharma Sciences and Research (IJPSR), 1(8), 278-281.
Putri, A.Y., Yurina, V., and Hidayati, D.Y.N. (2016). $\alpha$-Mangostin Dari Ekstrak pericarp Manggis (Garcinia mangostana L.) Mampu Menghambat Sekresi Culture Filtrate Protein-10 (CFP-10) pada Mycobacterium tuberculosis H37Rv. Pharmaceutical journal of indonesia, 2(1), 12-17.

Setiawati, A., Riswanto, F.O.D., Yuliani, S.H., and Istyastono, E.P. (2014). Anticancer Activity of Mangosteen Pericarp Dry Extract Against Mcf-7 Breast Cancer Cell Line Through Estrogen Receptor -A. Indonesian J. Pharm, 25(3), 119-124.

Aisha, A.F.A., Abu-Salah, K.M., Ismail, Z., and Abdul Majid, A.M.S. (2013). Determination of total xanthones in Garcinia mangostana fruit rind extracts by ultraviolet (UV) spectrophotometry. J. Med. Plants Res, 7(1), 29 ? 35.

Harborne, J.B. (2006). Metode Fitokimia: Penuntun Cara Modern Menganalisis Tumbuhan. Edisi Ke-2. Bandung: ITB.

Harmita. (2014). Analisis Fisikokimia: potensiometri \& spektroskopi. Jakarta: EGC.

Gandjar, I.G. and Rohman, A. (2012). Analisis Obat Secara Spektrofotometri dan Kromatografi. Yogyakarta: Pustaka Pelajar

Harmita. (2004). Petunjuk Pelaksanaan Validasi Metode dan Cara Perhitungannya. Majalah Ilmu Kefarmasian, 1(3), 117-135.

Andayani, R., Novita, R., and Verawati. (2015). Pengaruh metode ekstraksi terhadap kadar xanthone total dalam ekstrak kulit buah manggis matang (Garcinia mangostana L.) dengan metode spektrofotometri ultraviolet. Prosiding Seminar Nasional \& Workshop *Perkembangan Terkini Sains Farmasi \& Klinik 5*, 353-361.

Muchtaridi,M., Suryani,D., Qosim, W.A., Saptarini, N.M. (2016). Quantitative analysis of $\alpha$ mangostin in mangosteen (garcinia mangostana 1.) Pericarp extract from four district of west java by hplc method. Int J Pharm Pharm Sci, 8(8), 232-236.

Agustina, R., Andayani, R., and Dachriyanus. (2014). Development and validation of Thin-Layer Chromatographic method for determination of $\alpha$-mangostin in young pericarp, ripe pericarp and bark extract of Garcinia mangostana L. using TLC-Densitometry. Int. J. Res. Pharm. Sci, 5(4), 294-298.

Ahmad, N.R. (2012). Cara mudah mencegah dan mengobati kanker dengan ramuan tradisional dan alami. Yogyakarta: Aulya Publishing. 
Aisha, A.F.A., Abu-Salah, K.M., Ismail, Z., and Abdul Majid, A.M.S. (2013). Determination of total xanthones in Garcinia mangostana fruit rind extracts by ultraviolet (UV) spectrophotometry. J. Med. Plants Res, 7(1), 29?35.

Andayani, R., Novita, R., and Verawati. (2015). Pengaruh metode ekstraksi terhadap kadar xanthone total dalam ekstrak kulit buah manggis matang (Garcinia mangostana L.) dengan metode spektrofotometri ultraviolet. Prosiding Seminar Nasional \& Workshop *Perkembangan Terkini Sains Farmasi \& Klinik 5*, 353-361.

Chaverri, J.P., Rodriguez, N.C., Ibarra, M.O., and Rojas, J.M.P. (2008). Medicinal Properties of Mangosteen (Garcinia mangostana). Food and Chem. Tox, 46, 3227-3239.

Gandjar, I.G. and Rohman, A. (2012). Analisis Obat Secara Spektrofotometri dan Kromatografi. Yogyakarta : Pustaka Pelajar

Harborne, J.B. (2006). Metode Fitokimia : Penuntun Cara Modern Menganalisis Tumbuhan. Edisi Ke-2. Bandung : ITB.

Harmita. (2014). Analisis Fisikokimia : potensiometri \& spektroskopi. Jakarta : EGC.

Harmita. (2004). Petunjuk Pelaksanaan Validasi Metode dan Cara Perhitungannya. Majalah Ilmu Kefarmasian, 1(3), 117-135.

Mahabusarakam, W., Kuaha, K., Wilairat, P., and Taylor, W.C. (2006). Prenylated xanthones as potential antiplasmodial substances, Planta Med., 72(10), 912-916.

Muchtaridi,M., Suryani,D., Qosim, W.A., Saptarini, N.M. (2016). Quantitative analysis of $\alpha$ mangostin in mangosteen (garcinia mangostana 1.) Pericarp extract from four district of west java by hplc method. Int J Pharm Pharm Sci, 8(8), 232-236.
Pasaribu, F., Sitorus, P.,and Bahri, S. (2012). Uji Ekstrak Etanol Kulit Buah Manggis (Garcinia mangostana L.) Terhadap Penurunan Kadar Glukosa Darah. Journal of Pharmaceutics and Pharmacolog, 1(1), 1-8.

Pothitirat, W. and Gritsanapan, W. (2008). Quantitative analysis of total mangostins in Garcinia mangostana fruit rind.J Health Res, 22(4), 161-166.

Pradeep kumar, S.V., S. B. Puranik., and Nandini, B. N. (2017). Evaluation of Alpha-Mangostin, Isolated and Purified from the Crude Extract of Garcinia mangostana for the AntiDiabetic, Anti-Inflammatory and Antioxidant Activity. Ijppr.Human, 8(2), 75-95.

Priya, V., Jainu, M., Mohan, S.K., Saraswathi, P., and Gopan, C.S. (2010). Antimicrobial Activity of Pericarp Extract of Garcinia Mangostana Linn. International Journal of Pharma Sciences and Research (IJPSR), 1(8), 278-281.

Putri, A.Y., Yurina, V., and Hidayati, D.Y.N. (2016). $\alpha$-Mangostin Dari Ekstrak pericarp Manggis (Garcinia mangostana L.) Mampu Menghambat Sekresi Culture Filtrate Protein-10 (CFP-10) pada Mycobacterium tuberculosis H37Rv. Pharmaceutical journal of indonesia, 2(1), 12-17.

Setiawati, A., Riswanto, F.O.D., Yuliani, S.H., and Istyastono, E.P. (2014). Anticancer Activity of Mangosteen Pericarp Dry Extract Against Mcf-7 Breast Cancer Cell Line Through Estrogen Receptor -A. Indonesian J. Pharm, 25(3), 119-124.

Suparni, I. and Wulandari, A. (2017). Sehat tanpa obat dengan manggis. Yogyakarta: Rapha Publishing. 